\title{
$\mathrm{Ni}$
}

\section{玉 尾皓平}

\section{Nickel}

Kohei TAMAO*

Properties, manipulations, preparative methods and typical reactions have been described for the following twelve representative nickel compounds which have been used and/or should be useful as catalysts and/or reagents for synthetic organic reactions: nickel(II) halides, bis (acetylacetonato) nickel(II), nickel peroxide, dichloro(bipyridyl)nickel(II), dihalobis (trialkylphosphine) nickel(II), dichlorobis (triphenylphosphine) nickel (II), dichloro $\{1,3$-bis (diphenylphosphino) propane $\}$ nickel (II), trans-chlorophenylbis (triphenylphosphine) nickel (II), tetracarbonylnickel ( 0$)$, bis $(\eta-1,5$ - cyclooctadienyl) nickel ( 0 ), tetrakis (triphenylphosphine) nickel ( 0 ), di- $\mu$-bromobis ( $1-3-\eta$-allyl) dinickel (II).

\section{1.はじめに}

ニッケル化合物を用いる有機合成は大部分，炭素一炭 素結合生成反応である。すなわち，不飽和化合物のオリ ゴメリゼーション, カルボニル化反応执よびカップリン グ反応である。触媒反応は $\mathrm{Ni}(I I) \rightleftarrows \mathrm{Ni}(0)$ サイクル で進行するので, 安定で取り扱いやすい $\mathrm{Ni}$ (II) 錯体を 使用することが多い。Ni（0) 錯体は一般に空気に対して 極めて鋭敏で分解しやすいので, 取り扱いには細心の注 意が必要である。古くから一般によく用いられているラ ネーニッケルなどについては省略した。ニッケル錯体の 合成, 性質, 反応一般については詳しい成書が出版され ている ${ }^{11}$ 。

\section{2. 主なニッケル化合物}

\section{$\circ \mathbf{N i C l}_{2}, \mathbf{N i C l}_{2} \bullet 6 \mathbf{H}_{2} \mathbf{O}, \mathrm{NiBr}_{2}, \mathrm{NiBr}_{2} \bullet 3 \mathrm{H}_{2} \mathrm{O}, \mathrm{NiI}_{2} \bullet 6$} $\mathbf{H}_{2} \mathbf{O}$ : 塩化ニッケル (II), 臭化ニッケル (II), ヨウ 化ニッケル（II）

製法：市販されている。完全無水物は使用直前に氷酢 酸で処理して得る。

性質：無水物は黄色固体，含水物は黄緑色〜緑色結晶。 いずれあ吸湿性（潮解性）であるが, 手早く秤量すれば よい。

応用：種々のニッケル錯体の合成原料となるほか, 活 性有機金属化合物および配位子などと組み合わせて，広

\footnotetext{
$*$ 京都大学工学部合成化学教室 口)

* Department of Synthetic Chemistry, Faculty of Engineering, Kyoto University
}

範囲に用いられている。臭化ニッケルは有機ハロゲン化 物とリチウムエノレートとのカップリングに有効”。ま た，ヨウ化ニッケルはカルボニル化に特に活性である゙”。 ○ $\mathrm{Ni}\left(\mathrm{CH}_{3} \mathrm{COCHCOCH}_{3}\right)_{2}$ または $\mathrm{Ni}(\mathrm{acac})_{2}$ : ビス (ア セチルアセトナト) ニッケル (II)

製法：2 水和物（淡青緑色結晶）として市販されてい る。無水物を得るには, 粉砕後, $110^{\circ} \mathrm{C} / 0.1 \mathrm{mmHg}, 24$ 時間乾燥するか, トルエンとの共沸で水分を除き，七ラ イトを通してろ過, ろ液を蒸発乾固後, 粉砕して $80^{\circ} \mathrm{C} /$ $0.1 \times 10^{-3} \mathrm{mmHg}$ で 16 時間乾燥する ${ }^{31}$ 。

性質: 安定な黄緑色結晶, $\mathrm{mp} 228^{\circ} \mathrm{C}$ 。

応用：ニッケル $(0)$ 錯体合成の重要な原料。アルキ ルアルミニウムなどと組み合わせた，いわゆる Ziegler 型を基本とする種々の触媒反応に用いられる。ジェン類 のオリゴメリゼーション（たとえば，ブタジエンからシ クロドデカトリエンの生成) ${ }^{11}$, トリメチルアルミニウム ${ }^{41}$ 扰よびアルケニルジルコニウム試薬 ${ }^{5}$ の $\alpha, \beta$-不飽和力 ルボニル化合物への 1,4-付加, 芳香族グリニャール試薬 とハロゲン化物とのクロスカップリング反応 ${ }^{6)}, ク^{\prime}$ クニ ヤール試薬のアセチレン結合への付加反応》1な゙。

\section{○過酸化ニッケル}

製法 ${ }^{8)}$ : 硫酸ニッケル (II) 水和物 $130 \mathrm{~g}$ の水溶液 (300 $\mathrm{ml})$ に $6 \%$ 次亜塩素酸ナトリウム $300 \mathrm{ml}$ と水酸化ナトリ ウム $42 \mathrm{~g}$ の混合物を滴下し, $20^{\circ} \mathrm{C}$ で 30 分間かきまぜる。 生成した黒色の過酸化ニッケルをろ別し, 塩素を除くた めに充分に水洗した後, 固体を粉砕して塩化カルシウム 上で減圧乾燥する。

活性酸素の定量法 ${ }^{8)}$ : 試料約 $0.2 \mathrm{~g}$ を精秤し, $2 \sim 3 \mathrm{~g}$ の $\mathrm{KI}$ を含む $36 \%$ 酢酸 $20 \mathrm{ml}$ に完全に溶解し, 密閉して 10 
分間放置後, 遊離ヨウ素を $0.1 N$-チオ硫酸ナトリウムで 滴定する。通常 $0.35 \times 10^{-2} \mathrm{~g}$-atom oxygen $/ \mathrm{g}$ 程度であ る。

$\frac{\mathrm{Na}_{2} \mathrm{~S}_{2} \mathrm{O}_{3}(\mathrm{ml})}{1,000 \times \text { peroxide }(\mathrm{g}) \times 10 \times 2}=\mathrm{g} \cdot$ atom $\cdot$ oxygen $/$

$\mathrm{g} \cdot$ nickel peroxide

再生方法: 反応後乃過, 水洗し, $6 \%$ 次亜塩素酸ナト リウム（過酸化ニッケルの量の約 10 倍）中で 20 分間か きまぜ, 万過, 水洗, 乾燥する。

性質：黒色固体。空気に対して安定だが密閉容器中で 保存する。

応用：アルコール，アルデヒドをはじめ種々の化合物 の酸化 ${ }^{8,9)}$ 。多くの反応で二酸化マンガンより活性が高い といわれている。

○ $\mathrm{NiCl}_{2}$ (bpy) : ジクロロ（ビピリジル）ニッケル (II)

製法 ${ }^{101}$ : エタノール中の無水塩化ニッケル（II）にわ ずかに過剩の $2,2^{\prime}$-ビピリジルのエタノール溶液を室温 で激しくかきまぜながら滴下する。数時間かきまぜ後， 生成した沈殿をろ過, アセトンで洗浄し乾燥することに よって，ほ心゙定量的に得られる。

性質：常磁性，黄緑色粉末。空気に安定。

応用：マグネシウム存在下での芳香族ジハロゲン化物 のカルボニル化を伴なう重縮合 ${ }^{11}$ など。

$\circ \mathbf{N i X}_{2}\left(\mathbf{R}_{3} \mathbf{P}\right)_{2}$ : ジハロビス (トリアルキルホスフィン) ニッケル（II）

製法：新実験化学講座 ${ }^{12)}$ p. 213。

性質：空気に安定で取り扱い易い。

応用：種々の還元剂と共に用いて，オレフィン，ジエ ン類のオリゴメリゼーションなどの触媒となる1〉。

○ $\mathbf{~ N i C l}_{2}\left(\mathbf{P P h}_{3}\right)_{2}$ : ジクロロビス（トリフェニルホスフ ィン) ニッケル（II）

製法 $^{13,14) ： ト リ フ ェ ニ ル ホ ス フ ィ ン ~} 5.25 \mathrm{~g}(0.02 \mathrm{~mol})$ を水酢酸 $75 \mathrm{ml}$ に溶かした熱溶液に，塩化二ッケル（II） 6 水和物 $2.38 \mathrm{~g}(0.01 \mathrm{~mol})$ の水 $(2 \mathrm{ml})$ 溶液を加える。 直ちに暗緑色の結晶が析出する。放冷後, 万過, 少量の 酢酸で洗浄後減圧乾燥する。収率 $80 \%$ 以上。

性質：空気に安定な暗緑色結晶， $\mathrm{mp} 247 \sim 250^{\circ} \mathrm{C}$ 。

応用：グリニャール試薬と有機ハロゲン化物 ${ }^{15)}$ あるい

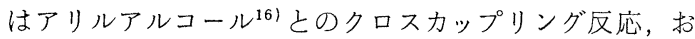
よびグリニャール試薬のアセチレンへの付加反応 ${ }^{17)}$ の触媒, など。

○ $\mathbf{N i C l}_{2}\left(\mathbf{P h}_{2} \mathbf{P C H}_{2} \mathbf{C H}_{2} \mathbf{C H}_{2} \mathbf{P P h}_{2}\right)$ または $\mathbf{N i C l}_{2}$ (dppp)

: ジクロロ [1,3-ビス（ジフェニルホスフィノ）プロ パン] ニッケル（II）

製法 ${ }^{18,19)}$ : 空気中で行なえる。塩化ニッケル（II） 6
水和物 $9.5 \mathrm{~g}(0.040 \mathrm{~mol})$ を 2 -プロパノール/メタノール $5 / 2$ (体積) 混合溶媒 $175 \mathrm{ml}$ に溶加し，加熱下にかきま ぜながら，1,3-ビス（ジフェニルホスフィノ）プロパン $14.5 \mathrm{~g}(0.035 \mathrm{~mol})$ の2-プロパノール $(200 \mathrm{ml})$ 熱溶液 を加える。直ちに赤色結晶が析出する。さらに 30 分間加 熱後, 放冷し, 万過，メタノールで洗浄後减圧乾燥する。 収率はほぼ定量的。

同様の方法で, ジクロロ $[1,2-$ ビス (ジフェニルホス フィノ）エタン] ニッケル（II）， $\mathrm{NiCl}_{2}$ (dppe)，あ合成 できる。な技，配位子はトリフェニルホスフィンから合

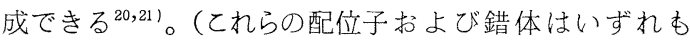
Strem 加ら市販むされている)。

性質：赤色微結晶。空気に安定

応用：グリニャール試薬と有機ハロゲン化物とのクロ スカップリング反応の触媒 ${ }^{15,19 !}$ 。

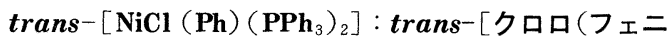
ル）ビス（トリフェニルホスフィン）ニッケル（II )]

製法：新実験化学講座 ${ }^{12)}$ p. 217 。

性質：黄色結晶。空気に比較的安定なので空気中で秤 量できるが，保存は窒素（アルゴン）下。

応用：とのタイプの有機ニッケル錯体はルイス酸と組 み合わせると，オレフィンの共二量化の触媒となる ${ }^{22)}$ 。 また，有機金属化合物との反応によってフェニル基との カップリング生成物を与える ${ }^{23,24)}$

$\circ \mathrm{Ni}(\mathrm{CO})_{4}:$ テトラカルボニルニッケル $(0)$

製法：市販品。

性質：毒性, 取り扱い法などは新実験化学講座 ${ }^{121} \mathrm{p}$. 212 亿詳しく記載されている。毒性の強い気体で, 連日 使用する場合の許容濃度は $0.001 \mathrm{ppm}$ といわれている （青酸ガス, $10 \mathrm{ppm}$; 一酸化炭素, $100 \mathrm{ppm)。}$

応用：オレフィン，アセチレンなどのカルボニル化試 剂および触媒 ${ }^{(b)}$ となる。有機八ロゲン化物之組み合わせ るとアシル陽イオン活性種 ${ }^{25}$, 26) , 有機リチウム試薬など と組み合わせるとアシル陰イオン活性種 ${ }^{27}{ }^{28)}$ としての力 ップリング試剤となる291。

○ $\mathbf{N i}\left(\mathrm{C}_{8} \mathrm{H}_{12}\right)_{2}$ または Ni $(\mathbf{C O D})_{2}:$ ビス $(\eta-1,5$-シクロ オクタジエン) ニッケル (0)

製法：新実験化学講座 ${ }^{121}$, p. 227 に記載されているが, 詳しい改良法が報告されている3 ${ }^{3,29)}$ のでててでも述べる3!。 窒素気流下で行なう。1,5-シクロオクタジエンは過酸化 物不純物を除くために，Grade 1 の中性アルミナを通し てろ過する。アルミナが黄色にならなくなるまで繰り返 し，すぐ使用する。ブタジェンはType $3 \mathrm{~A}$ モレキュラ ーシーブ上にー $78^{\circ} \mathrm{C}$ で凝縮保存して乾燥する。

$1 l$ 四つロフラスコにガス導入管, 温度計, 执よびドラ 
イアイス冷却管をつける。中央のロから, ビス(アセチル アセトナト) ニッケル (II) $102.8 \mathrm{~g}(0.4 \mathrm{~mol})$, トルエン $250 \mathrm{ml}$ および 1,5-シクロオクタジエン $216 \mathrm{~g}(2.0 \mathrm{~mol})$ を入れる。中央の口にかきまぜ棒を装備し，かきまぜな がら $-10^{\circ} \mathrm{C}$ に冷却し, 冷却管にドライアイス拈よびアセ トンを満たす。約 $18 \mathrm{~g}(0.33 \mathrm{~mol})$ のブタジエンを導入溶 解する。ガス導入管を等圧滴下漏斗にとりかえ，てれに， トリエチルアルミニウム $103 \mathrm{~g}(0.9 \mathrm{~mol})$ のトルエン $(100$ $\mathrm{ml}$ ) 溶液を移し (注射器使用), 温度を $-10^{\circ} \mathrm{C} \sim 0^{\circ} \mathrm{C}$ 亿保 ち 45〜90 分かかってゆっくり滴下する。反応混合物は

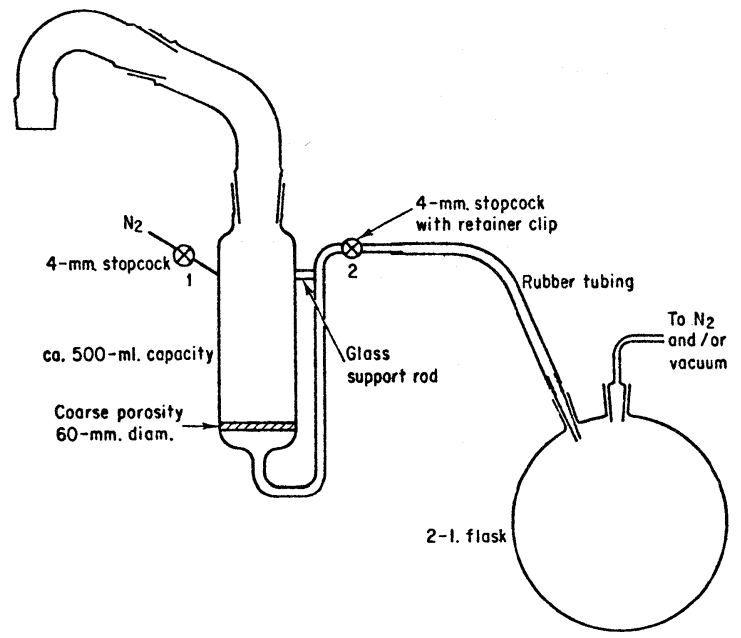

Fig. 1 Apparatus for low temperature filtration (ref.3).

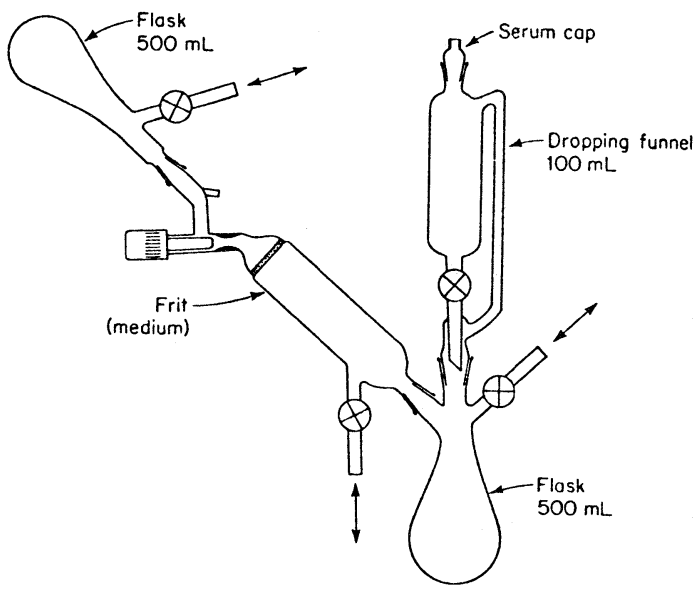

Fig. 2 Apparatus for the preparation and filtration of air-sensitive compounds (ref. 30).

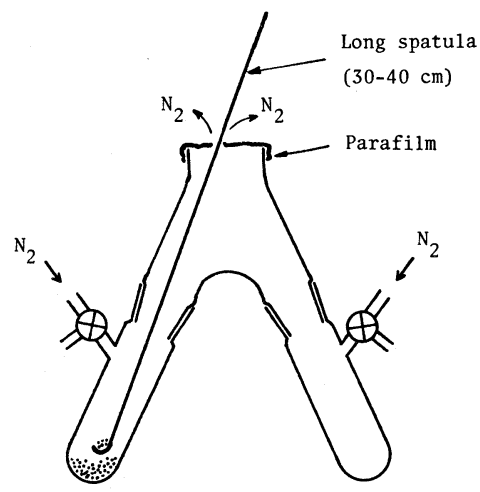

Fig. 3 Apparatus for transfer of air-sensitive compounds.

緑色から黄褐色となり黄色結晶が析出する。 $0^{\circ} \mathrm{C}$ で 30 分 間，室温で一晚かきまぜる。 $-15^{\circ} \mathrm{C}$ に冷却して $2 \sim 3$ 時 間加きまぜた後, 窒素加圧下にろ過, $-15^{\circ} \mathrm{C}$ のトルエン $(100 \mathrm{ml} \times 3$ 回）执よ゙冷無水エーテルで洗浄する。 $-15^{\circ} \mathrm{C}$ で約 30 分間减压乾燥後, $25^{\circ} \mathrm{C} / 0.1 \times 10^{-3} \mathrm{mmHg}$ で 16 時間乾燥する。収量 $97.0 \mathrm{~g}$ (89\%収率)。万過は図 1 のような装置を用いて行なうが，図 2 のような反応装 置を用い室温で手早くろ過しても収率にあまり影響しな い。な抏，乙のような空気に不安定な化合物の移しかえ には図 3 のような装置を使うと便利である。

性質 : 黄色板状晶, $\mathrm{mp}$. 約 $135 \sim 140^{\circ} \mathrm{C}$ (分解)。空気中 に出すと数分間で分解する。窒素（アルゴン）下で取り 扱う。

応用：他の $\mathrm{Ni}(0)$ 錯体合成の原料となる ${ }^{301}$ 。ジエン

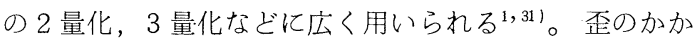
った炭素一炭素結合の切断に対して活性である ${ }^{321}$ 。有機 ハロゲン化物のカップリング剂となる ${ }^{33,34)}$ 。特に, 2,2 -

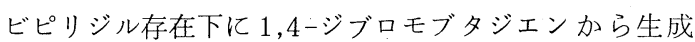
するニッケラシクロペンタン化合物, (bpy) $\mathrm{Ni}\left(\mathrm{CH}_{2}\right)_{4}$, の反応は特に興味深い ${ }^{34)}$ 。

$\circ \mathrm{Ni}\left(\mathrm{PPh}_{3}\right)_{4}$ : テトラキス（トリフェニルホスフィン） ニッケル (0)

製法: 新実験化学講座 ${ }^{121}$, p. 214 に記載されている。 またビス (ク-1,5-シクロオクタジェン) ニッケル $(0)$ か らの合成法む報告されている30)。

性質：赤褐色結晶, mp. $123 \sim 128^{\circ} \mathrm{C}$ (窒素下)。空気に対 してきわめて鋭敏で発火することあある。

応用: 有機ニッケル錯体の合成原料。有機ハロゲン化 物のカップリング剂として有効 ${ }^{35 !}$ 。有機ハロゲン化物と 活性有機金属化合物とのクロスカップリング反応の触媒 として屯用いられる ${ }^{36,371}$ が，空気にきわめて不安定なた 
め, 安定な $\mathrm{Ni}$ (II) 化合物を使いて in situで還元して そのまま使用するのが実用的である。たとえば，古くか ら用いられている $\mathrm{Ni}(\mathrm{acac})_{2} / \mathrm{PPh}_{3} / \mathrm{R}_{3} \mathrm{Al}$ の系 ${ }^{38,39)}$ ある いは $\mathrm{NiCl}_{2}\left(\mathrm{PPh}_{3}\right)_{2} / \mathrm{Zn} / \mathrm{PPh}_{3} / \mathrm{DMF}$ 系 ${ }^{40,41)}$ などである。

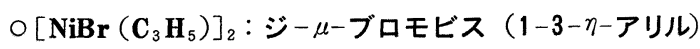
ニニッケル (II)

製法 : 新実験化学講座 ${ }^{121}$, p. 221 亿記載があるが, 有 機反応試剂として用いる場合, 単離することなくそのま ま用いるととが多い。2つの例について述べる。

(A) ニッケルカルボニル $\mathrm{Ni}(\mathrm{CO})_{4}$ を用いる方法：

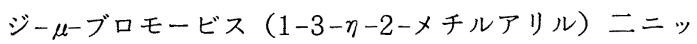
ケル： ${ }^{42}$ 還流冷却器, 等圧滴下漏斗, 三方コックおよび 磁気回転子をそなえた 11 三つロフラスコに，窒素気流 下に無水ベンゼン $300 \mathrm{ml}$ を入れ， テトラカルボニルニ ッケル（0） $50.8 \mathrm{~g}(38.5 \mathrm{ml} ; 0.298 \mathrm{~mol})$ を加える。フ ラスコを $50^{\circ} \mathrm{C}$ の油浴につけ,臭化2-メチルアリル10.04 g (0.0745 mol) を 10 分間で加える。しばらくすると一酸 化炭素が発生しはじめ, 濃赤色となる。ガスの発生が激 しくなったら $70^{\circ} \mathrm{C}$ にげ，ガス発生終了後あ 30 分間こ の温度に保つ。（臭化 2 -メチルアリルの滴下から 1.5 時 間)。 $25^{\circ} \mathrm{C}$ に冷却後, ベンゼンと過剩のニッケルカルボ ニルを水流ポンプで留去, 蒸発乾固する。残った赤色固 体はそのままアリル化反応（下記参照）などに使用し得 る。収率 $85 \%$ となしてよい。

純粋な化合物を得るには, 固体を, 酸素を含まない無 水エーテルに溶かし，アルゴン下でろ過，乃液を結晶が 析出し始めるまで濃縮し, $-78^{\circ} \mathrm{C} に 12$ 時間放冷後, 液 体部分を除去する。収量 $12.1 \mathrm{~g}$ (収率 $85 \%$ )。

(B) ビス ( （０）を用いる方法： ${ }^{29)} 三$ 万コックとシーラムキャップを 備えたフラスコにビス（ク-1,5-シクロオクタジェン) ニ ッケル $(0), \mathrm{Ni}(\mathrm{COD})_{2}, 8.879 \mathrm{~g}(32.4 \mathrm{mmol})$ を入れ, 酸素を含まない乾燥ベンゼン $50 \mathrm{ml}$ を注射器で加え, 続 いて 2-(ブロモメチル)アクリル酸エチル $4.40 \mathrm{ml}$ (6.26 g; $32.4 \mathrm{mmol}$ )を $25^{\circ} \mathrm{C}$ で 30 分加加て加える。直ちに濃 赤色になる。さらに 30 分間 $25^{\circ} \mathrm{C}$ に保った後, 反応混合 物を窒素下にろ過，乃液を結晶が析出しはじめるまで $25^{\circ} \mathrm{C} / 25 \mathrm{mmHg}$ で濃縮し, ペンタン $25 \mathrm{ml}$ を加えて $0^{\circ} \mathrm{C}$ に冷却して完全に結晶化させる。上と同様にろ過, 洗浄 (ペンタン) し, 減圧乾燥 $\left(25^{\circ} \mathrm{C} / 0.1 \mathrm{mmHg}\right)$ する。収 量 $6.17 \mathrm{~g}$ (収率 $76 \%$ )。

性質：一般に空気に不安定な暗赤色結晶。

応用: 特にオレフィンの二量化触媒として有効。たと えば, 不斉二量化反応 ${ }^{43)}$ な゙。また, イソプレンの三量 化によるテルペン合成の触媒として用いられる ${ }^{44)}$ 。有機
八ロゲン化物，カルボニル化合物およびキノンなどのア リル化試剂として用いられている ${ }^{29,45 ! 。 ~}$

(昭和 54 年 7 月 24 日受理)

\section{文献}

1a) P.W.Jolly, G.Wilke, "The Organic Chemistry of Nickel" Vol. 1 (1975) Academic Press, New York

b) Vol. 12 (1975)

2) A.A.Millard, M.W.Rathke, J. Am. Chem. Soc。, 99, 4833 (1977)

3) R.A.Schunn, "Inorganic Symtheses", 15, 5 (1974)

4) L. Bagnell, E.A. Jeffery, A. Meisters, T.Mole, Austr. J. Chem., 28, 801 (1975)

5) M.J.Loots, J.Schwartz, J. Am. Chem. Soc, 99, 8045 (1977)

6) R.J.P.Corriu, J.P.Masse, J. Chem. Soc. Chem. Commun., 1972, 144

7) B.B.Snider, M.Karras, R.S.E.Conn, J. Am. Chem. Soc., 100, 4624 (1978)

8) K. Nakagawa, R. Konaka, T.Nakata, J. Org. Chem., 27, 1597 (1962)

9) K.Nakagawa, H. Onoue, K. Minami, J. Chem. Soc., Chem. Commun., 1966, 17

10) M.Uchino, K. Asagi, A. Yamamoto, S.Ikeda, J. Organometal. Chem., 84, 93 (1975)

11) T. Yamamoto, A. Yamamoto, Chem. Lett., 1977,353

12）新実験化学講座, 12 巻

13) L.M.Venanzi, J. Chem. Soc., 1958, 719

14) F.A.Cotton, O.D.Faut, D.M.L.Goodgame, J. Am. Chem. Soc., 83, 344 (1961)

15) K.Tamao, K.Sumitani, Y.Kiso, M.Zembayashi, A.Fujioka, S.Kodama, I. Nakajima, A. Minato, M.Kumada, Bull. Chem. Soc. Jpn., 49, 1958 (1976)

16) H.Felkin, E. Jampel-Costa, G.Swierczewski, J. Organometal. Chem., 134, 265 (1977)

17) J.G.Duboudin, B. Jousseaume, Compt. Rend., 276, 1421 (1973)

18) G.R.Van Hecke, W.D. Horrocks, Jr., Inorg. Chem., 5, 1968 (1966)

19) M.Kumada, K. Tamao, K.Sumitani, "Organic Symtheses", 58, 127 (1978)

20) W.Hewertson, H.R.Watson, J. Chem. Soc., 1962,1490

21) K.Sommer, 'Z. Anorg. Allgem. Chem., 376,37 (1970)

22) N. Kawata, K. Maruya, T.Mizoroki, A. Ozaki, Bull. Chem. Soc. Jpn., 47, 2003 (1974)

23) M.F.Semmelhack, R.D.Stauffer, and T.D. Rogerson, Tetrahedron Lett., 1973, 4519

24) G.W.Parshall, J. Am. Chem. Soc., 96, 2360 
(1974)

25) E.J.Corey, L.S.Hegedus, J. Am. Chem.Soc., 91, 1233 (1969)

26) I.Rhee, M.Ryang, H.Hasegawa, S. Murai, N.Sonoda, Chem. Lett., 1978, 15

27) Y.Sawa, I. Hashimoto, M.Ryan, S.Tsutsumi, J. Org. Chem., 33, 2159 (1968)

28) E. J. Corey, L.S.Hegedus, J. Am. Chem. Soc., 91, 4926 (1969)

29) M.F.Semmelhack, "Organic Reactions", 19, 117 (1972)

30) S.D.Ittel, "Inorganic Syntheses", 17, 117 (1977)

31) W.E.Billups, J.H.Cross, C.V.Smith, J. Am. Chem. Soc., 95, 3438 (1973)

32) R. Noyori, M. Yamakawa, H.Takaya, J. Am. Chem. Soc., 98, 1471 (1976)

33) M.F.Semmelhack, P.M. Helquist, J.D.Gorzynski, J. Am. Chem. Soc., 94, 9234 (1972)

34) S. Takahashi, Y.Suzuki, K. Sonogashira, N. Hagihara, J. Chem. Soc., Chem. Commun., 1976, 839

35) M.F.Semmelhack, L.S.Ryono, J. Am. Chem.
Soc., 97, 3873 (1975)

36) L. Cassar, J. Organometal. Chem., 54, C 57 (1973)

37) J.F.Fauvarque, A.Jutand, J. Organometal. Chem., 132, C 17 (1977)

38) S.Baba, E.Negishi, J. Am. Chem. Soc., 98, 6729 (1976)

39) M.Mori, Y.Ban, Tetrahedron Lett., 1976 , 1803

40) A.S.Kende, L.S. Liebeskind, D.M. Braitsch, Tetrahedron Lett., 1975, 3375

41) M. Zembayashi, K. Tamao, J. Yoshida, M. Kumada, Tetrahedron Lett., 1977, 4089

42) M.R.Semmelhack, P.M.Helquist, "Organic Symtheses", 52, 115 (1972)

43) B. Bogdanovic, B.Henc, A.Loster, B.Meister, H.Pauling, G. Wilke, Angew. Chem., 85,1013 (1973)

44) S. Akutagawa, T. Taketomi, H. Kumobayashi, K. Takayama, T.Someya, S. Otsuka, Bull. Chem. Soc. Jpn., 51, 1158 (1978)

45) L.S.Hegedus, J. Organometal. Chem. Libra$r y, \quad 1,329$ (1976)

\section{お 知 らせ ?}

かねてよりお知らせしてまいりましたように，本年 （1979 年）1月より報文，ノートの Synopsis化を実施 致しております。これに伴う新料金(「第 37 巻第 1 号」 掲載分から適用) を下記のごとく決めましたのでお知 らせ致します。

揭載された抄報の原報のマイクロフィッシュおよび そのコピーを希望される方は規定の代金を添えて（現 金書留，または郵券) お申し込み下さい。

記

() 投稿料 10,000 円

（抄報の別刷 50 部，原報のマイクロフィッ シュとそのコピー（B 5 判）各 1 部を含む)
（）原報のマイクロフィッシュ 1 部 500 円

（）原報のコピー（B 5 判） 1 ページ* 50 円 [前金, 郵送料込み]

（＊原報のページ数は抄報に記載されています。 国外宛航空便は別途取扱います。)

なお，「投稿規定」，「原稿執筆の手引」は11月号に， 抄報の “ひな型”・ は昨年 (第 36 巻) $10 \sim 12$ 月号なら びに本年 1，3，9，10月の各号に抄報が掲載されてお りますので，ご投稿の際はこれらをご参照下さい。 